\title{
China's ban of imported recyclable waste and its impact on the waste plastic recycling industry in China and Taiwan
}

\author{
Aya Yoshida ${ }^{1}$ (D)
}

Received: 26 December 2019 / Accepted: 6 September 2021 / Published online: 23 September 2021

(c) The Author(s) 2021

\begin{abstract}
In 2017 the Chinese government announced to a ban on the importation of several kinds of recyclable waste that could be replaced by domestic recyclable waste. Current research on this subject has placed an emphasis on the issues faced by exporting countries and Southeast Asia as an alternative destination of plastic wastes. However, there has been little study on changes in the waste recycling industry in China and other export destinations such as Taiwan. In this study, I conducted a field survey in China and Taiwan and reviewed the history of Chinese recyclable waste import policy and its impacts on plastic recycling industries. The results show that China switched from directly importing waste plastics from exporting countries to importing recycled pellets via third-party countries, primarily from Southeast Asia. Although Taiwan's import volume of waste plastics has increased since 2018, improper (i.e. illegal) imports such as those commonly reported in Southeast Asian countries have not been reported in Taiwan. Even after Taiwan implemented tightened import controls in October 2018, it was still able to import enough recycled waste to meet domestic demand. The case of Taiwan shows that proper import controls can contribute to a more sustainable global circular economy.
\end{abstract}

Keywords Waste trade $\cdot$ Foreign waste ban $\cdot$ Recycled pellets $\cdot$ Circular economy

\section{Introduction}

China has imported recyclable waste, such as iron scrap and waste plastics, from abroad to make up for a shortage of domestic resources [1]. After China joined the World Trade Organization (WTO) in 2001, its demand for raw materials dramatically increased due to rapid industrial development. Several studies have pointed out that importing recyclable waste can have multiple benefits. For example, recycling imported waste can consume less energy and generate less residue compared to producing similar materials from virgin natural resources [2]. Imported recyclable waste represents a stable supply of high-quality materials and generates high profits for recycling industries [3, 4]. Waste imports also contributed to reducing China's trade deficits after it joined the WTO [5, 6]. However, there are also several problems associated with imported recyclable waste. Environmental contamination caused by small-scale recyclers has been well

Aya Yoshida ayoshida@nies.go.jp

1 National Institute for Environmental Studies, Tsukuba, Japan documented [3, 7]. In addition, with high profits as the driving force, some importers engaged in the unauthorized (i.e., illegal) use of import licenses or resale of imported recyclable waste. The amount of smuggled recyclable waste has been estimated to be dozens of times the amount allowed by government regulations [8].

The State Council announced that China would begin prohibiting the importation of 24 types of recyclable waste beginning at the end of 2017 [9]. In addition, China gradually stopped the importation of recyclable waste that can be replaced by domestic waste starting at the end of 2019. As a result, the importation of household waste plastics was banned by the end of 2017, and the importation of waste metal and electrical appliance scraps was banned by the end of 2018. This sudden policy change is known as the "China Ban" or "China Shock" and has had a major impact on global trade in plastic waste [10].

Several studies have explored the responses of the major industrialized countries to the China Ban. After the Ban, waste plastics began to pile up in these countries, including the United States, Canada, Germany, and other Western European countries [11-13]. Previously recyclable waste has become garbage to be landfilled because it has no market 
value $[14,15]$. Some recyclers or waste dealers started to ship the waste to other countries, such as Malaysia, Indonesia, India, and Vietnam [12-15]. France, United Kingdom, Ireland, and some states in the US have taken actions to restrict the use of plastics $[12,16]$. In Japan, the export volume of waste plastics to China declined sharply in 2018, and more waste plastics have been exported to Southeast Asia and Taiwan since 2018 [17]. The overall level of exports decreased and more waste plastics have remained in Japan. As a result, the price of treating industrial waste plastics has increased by a factor of two to three [18].

Because they faced an increased amount of improper (i.e., unregulated or illegal) imports, Southeast Asian countries were forced to restrict waste imports in the middle of 2018 $[17,19,20]$. In contrast, although Taiwan's imports also increased, there were few reported cases of improper imports in Taiwan. According to trade statistics in 2015-2018, the average unit price of waste plastics imported into Taiwan was $0.4-0.5 \mathrm{USD} / \mathrm{kg}$, compared to $0.2-0.3 \mathrm{USD} / \mathrm{kg}$ in Malaysia and Thailand [25, 29]. The higher price indicates there are relatively "clean" (i.e., high-quality) materials, but why are relatively clean waste plastics being imported into Taiwan? To date, little information has been available about the impact of the China Ban on the plastic waste industry in Taiwan.

In this paper, I discuss the impacts of the China Ban and its effects on the waste plastic recycling industries in China and Taiwan. In the next section, I describe the materials and methods used in the study. I then give a brief overview of the history of Chinese recyclable waste import policy, the development of the Chinese plastic recycling industry, and changes in the waste plastic trade volume before and after the China Ban as well as other changes in the waste plastic industry in China. I also outline changes in the trade volume of Taiwan and the import restrictions it imposed after the China Ban. Finally, I discuss the China Ban's impact on the waste plastic recycling industry in China and Taiwan and the challenges facing international trade in waste plastics.

\section{Materials and methods}

I conducted field surveys in China in March 2018 and February 2019, and in Taiwan in February 2019. Interviews with officials of China's Ministry of Ecology and Environment (MEP) were conducted in March 2018. I also conducted several interviews with officials of relevant industry associations in China and Taiwan. Information was also obtained through interviews of three Japanese waste plastics exporters and three Chinese recyclers, and through informal information exchanges at four relevant seminars and conferences of the plastic recycling industry in Japan from December 2018 to October 2020. In addition, I gathered information through an internet search of relevant news articles, reports, and research papers written in both Chinese and English. Relevant trade statistics of China and Taiwan were also analyzed.

\section{A history of Chinese recyclable waste import policy}

\section{The "Closed-loop management system"}

In the early 1990s, foreign waste that was being imported as "recyclable waste" was causing serious problems in China [21]. The Chinese government made a temporary statement in 1991 to control the importation of hazardous waste and enacted domestic legislations to regulate waste imports in 1996. Several government agencies, including the Ministry of Environment Protection (MEP) (current MEE), China Customs, and the General Administration of Quality Supervision, Inspection and Quarantine (AQSIQ), established the so-called "Closed-Loop Management System" for imported recyclable waste (Fig. 1) [22]. Various measures were introduced and implemented, such as MEP's import permit system in 1997, AQSIQ's pre-shipment inspection system of import recyclers (2003), and AQSIQ's registration system of overseas exporters and domestic consignees (2007). The closed-loop system has achieved some success in the reduction of rejected goods, deregistration of inappropriate suppliers, and the return of inappropriate materials [23]. Recyclers of waste metal and electrical appliance scraps became concentrated in industrial parks both to expand the scale of production and to facilitate government monitoring and supervision of operations.

Environmental standards for importable recyclable waste have been set by the government to control the quality of imported recyclable waste. Table 1 shows the percentage of contamination allowed in imported recyclable waste in 1996, 2005, and 2017. In general, the requirements grew stricter over time, but the contamination rate of waste plastic increased from $<0.1 \%$ to $<0.5 \%$ from 1996 to 2005 . Although PET bottles had previously only been allowed to be imported after cleaning and crushing, the government has allowed the importation of baled waste PET bottles (block cubes) since September 2014. Imports of recyclable waste originating from certain areas were also banned. For instance, a ban was placed on waste plastic originating in Japan from May 2004 to September 2005 because of previous shipments of improper imports from Japan to Qingdao.

\section{Pathway to the China Ban}

A series of environmental regulations were implemented prior to the Ban. These include the Green Fence (Lv Li Xing 
Fig. 1 The "Closed-Loop Management System" for imported recyclable waste in China. Note: GACC General Administration of China Customs, $A Q S I Q$ General Administration of Quality Supervision, Inspection and Quarantine, MEP Ministry for the Environment Protection, CCIC China Certification and Inspection (Group) Co., Ltd. Source: Department of Pollution Prevention and Control, MEP [22]

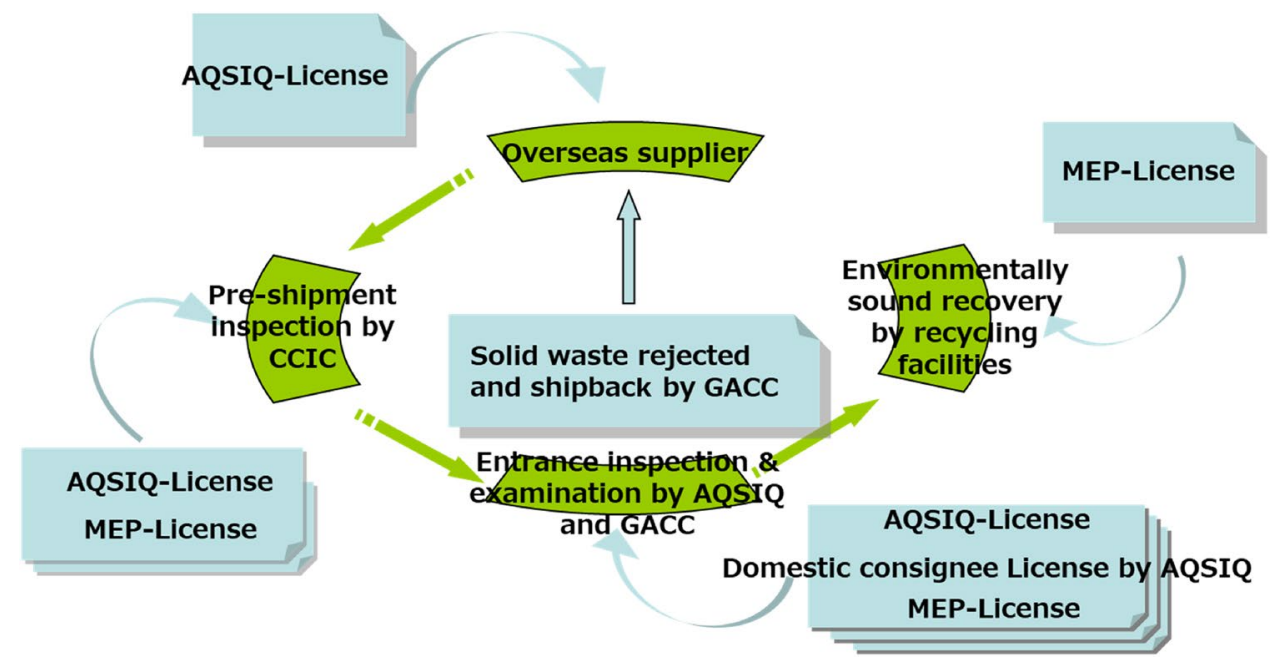

Table 1 Allowable contamination rates for imported recyclable waste in China in 1996, 2005, and 2017

\begin{tabular}{llll}
\hline & 1996 & 2005 & 2017 \\
\hline Waste paper or paperboard & $\leq 2.5 \%$ & $\leq 1.5 \%$ & $\leq 0.5 \%$ \\
Waste fibers & $\leq 1 \%$ & $\leq 1 \%$ & - \\
Waste iron and steel & $\leq 2 \%$ & $\leq 2 \%$ & $\leq 0.5 \%$ \\
Nonferrous metal scraps & $\leq 4 \%$ & $\leq 2 \%$ & $\leq 1 \%$ \\
Waste motors, waste wires and cables & $\leq 2 \%$ & $\leq 2 \% \quad \leq 0.5 \%$ \\
Waste metal and electrical appliance & $\leq 4 \%$ & $\leq 2 \%$ & $\leq 0.5 \%$ \\
$\quad$ scraps & & & \\
Waste plastics & $\leq 0.1 \%$ & $\leq 0.5 \%$ & $\leq 0.5 \%$ \\
\hline
\end{tabular}

Note: The environmental standard for waste fibers in 2017 was abolished because the importation of household waste plastics was banned by the end of 2017. Source: Compiled from the environmental standards in 1996, 2005 and 2017

Dong) campaign in 2013, the National Sword (Guo Men Li Jian) campaign in 2017, and the Blue Sky (Lan Tian) campaign in 2018. The main purpose of these campaigns was to crack down on the illegal importation (smuggling) of recyclable waste. I interviewed MEE officials in March 2018 and industry officials in February 2019, but found no indication that any single serious incident or incidents were responsible for the China Ban.

In fact, documents related to the government's implementation of the campaigns noted above almost always refer to a concept first presented at the 18th National Representative Congress of the Communist Party of China (November 2012) that promoted "green development, development of circulation, development of (a) low carbon (society), and constructing a beautiful China." This implies that the origin of these regulatory campaigns is environmental protection and the establishment of a green society as introduced by $\mathrm{Xi}$ Jin Ping in 2012. One interviewee said that the documentary film, "Plastic China," released in November 2016 might have contributed to the China Ban. The movie has given a negative impression to the general public about how plastic recycling threatens the ecological environment and people's health. However, based on my interviews with government and industry officials, it seems likely that although the movie may have accelerated the introduction of the import ban, it was probably not a direct trigger of it.

Prior to the introduction of the regulatory campaigns and the implementation of the China Ban, domestic waste generation in China increased rapidly. In 2014, the volume of municipal solid waste was 179 million $t$ and the generation of industrial waste was 3.25 billion $t, 1.5$ and 4 times the respective amounts in 1999 . In recent years, due to the increase in demand for home delivery of consumer products, the generation of container and packaging waste has also rapidly increased. Therefore, increasing the collection and recycling rates of domestic waste plastic in China to reduce the amount of waste being incinerated or landfilled also was probably a motivating factor behind the China Ban.

\section{History of the plastic recycling industry in China}

The Chinese recycling industry began to develop in the 1980s. Small-scale waste collectors were often seen on the street, but because China had a large gap between the supply of and demand for plastic resources, the waste plastics recycling industry developed rapidly. The China Plastic Recycling Association defines five stages of development: Starting (1984-1994), Development (1994-2004), Maturity (2005-2007), Adjustment (2008-2013), and Transformation and Upgrading (2014-2017) [24].

Before the Starting stage (1984-1994), only a small number of state-owned and collective enterprises were involved in recycling in China. After 1984, individual enterprises developed rapidly, and people gradually involved in the 
waste plastic recycling process. By 1993, many plastics could be recycled, but the recovery rate was rather low.

The Development stage (1994-2004) was a period of vigorous development of the industry. Tens of thousands of family-owned companies joined the industry, and the industry recycling rate increased from less than about $22-30 \%$ or even higher. Partial recovery rates reached $60-80 \%$.

The Maturity stage (2005-2007) was a period in which the industry faced fierce competition. Large-scale enterprises emerged, and problems brought about by the unfettered development of the industry began to become apparent. However, market rectification and industry adjustment during this period were not obvious. Competitive pressure within the industry was mainly derived from disorderly competition related to market prices. The level of industry development was rather stable. At the same time, as people's awareness of recycling increased, the domestic collection rate of major commodities reached more than $70 \%$. Because of China's increasing industrialization, the demand for raw materials continued to expand, and the supply of domestic waste plastic materials did not meet market demand. During this period, the volume of imported waste plastics continued to increase.

During the Adjustment stage (2008-2013), many waste plastics recycling companies in China began to concentrate in certain areas, and these markets were constantly patrolled or restricted by regulatory authorities. In many cases, inspections were unannounced. In 2013, the 10-month Green Fence campaign was directed at the recycled plastics industry. Full inspections were conducted and the entire industry was subject to regulation. As a result, the industry began to face bottlenecks in its development. China's waste plastics recycling industry was entering a stage of transformation, especially in terms of updating recycling technologies. The importance of environmental protection was also beginning to be emphasized. China's waste plastics imports began to decline in 2013.

After the Green Fence campaign, China's environmental protection restrictions escalated as China entered the Transformation and Upgrading stage (2014-2017). Environmental protection regulations covering waste plastic recycling companies and recycled plastics distribution centers were more stringent, and waste plastics recycling companies also faced transformation of their businesses. During this period, Chinese waste plastics recycling companies were forced to shut down, transform their businesses by upgrading technology, or relocate their facilities overseas. After China officially launched the China Ban in July 2017, more attention was paid to the construction of a domestic collection and recycling system. Central state-owned enterprises, listed companies, and medium- and large-scale recycling enterprises began to engage in domestic collection and recycling.

\section{Waste plastics statistics in China}

\section{Trade statistics}

As a result of the Green Fence and other campaigns, the volume of imported waste plastics to China has been declining since 2013 (Fig. 2). Even after the 2017 campaign, nonhousehold (industrial) waste plastics were still considered to be importable in 2018. However, since few import licenses for waste plastics were actually issued, both household and non-household waste plastics were effectively banned, and the amount of waste plastic imported to China dropped sharply from 5.83 million $t$ in 2017 to 51,605 $t$ in 2018 .

Table 2 shows the top 10 countries/regions of origin of imports of waste plastics to China. Although Japan is the second largest single-country source after China, Hong
Fig. 2 Volume of waste plastics imported in China. Source: UN Comtrade (HS code: 3915 ) [25]

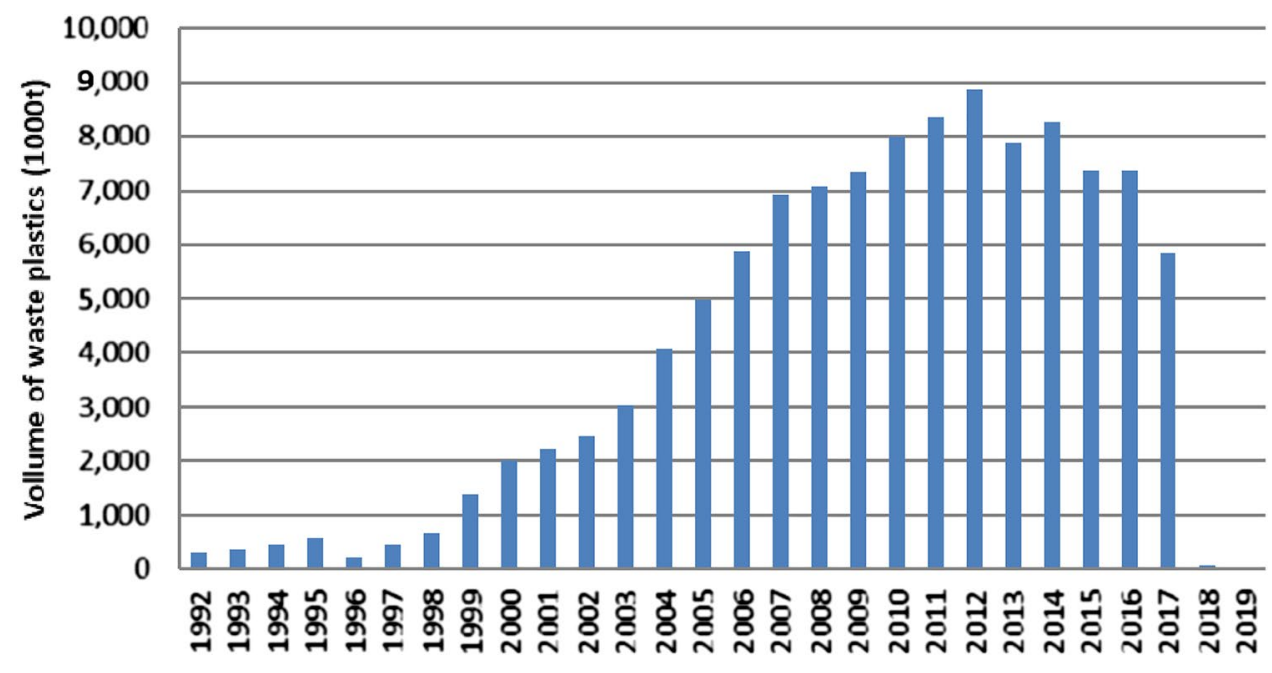


Table 2 Top 10 countries/ regions of origin for China's imported waste plastics

\begin{tabular}{lllllll}
\hline & 2015 & & 2016 & 2017 & \\
\hline 1 & EU-15 & $21 \%$ & China, Hong Kong SAR & $24 \%$ & EU-15 & $20 \%$ \\
2 & China, Hong Kong SAR & $21 \%$ & EU-15 & $18 \%$ & China, Hong Kong SAR & $16 \%$ \\
3 & Japan & $12 \%$ & Japan & $11 \%$ & Japan & $14 \%$ \\
4 & USA & $10 \%$ & USA & $9 \%$ & USA & $10 \%$ \\
5 & Thailand & $6 \%$ & Thailand & $6 \%$ & Thailand & $6 \%$ \\
6 & Canada & $3 \%$ & Philippines & $4 \%$ & Philippines & $5 \%$ \\
7 & Malaysia & $3 \%$ & Australia & $4 \%$ & Australia & $5 \%$ \\
8 & Republic of Korea & $3 \%$ & Indonesia & $3 \%$ & Indonesia & $3 \%$ \\
9 & Other Asia & $3 \%$ & Canada & $3 \%$ & Malaysia & $3 \%$ \\
10 & Philippines & $2 \%$ & Republic of Korea & $3 \%$ & Republic of Korea & $3 \%$ \\
\hline
\end{tabular}

Note: EU-15: Austria, Belgium, Denmark, Finland, France, Germany, Greece, Ireland, Italy, Luxembourg, the Netherlands, Portugal, Spain, Sweden and the United Kingdom. Source: UN Comtrade (HS code: 3915) [25]

Kong Special Administrative Region (SAR), it is the thirdlargest when the EU-15 is considered as one entity.

\section{Trade changes}

In my interviews with members of the Chinese Plastic Recycling Association and the China Resource Recycling Association in February 2019, interviewees stated that Chinese waste plastics importers had information about the import ban even before 2016. However, they did not know when it would be imposed until the official announcement in 2017.

There are a large number of waste plastics recycling companies in China, and collection networks are also spread throughout the country. During the Transformation and Upgrading stage, especially in 2016-2017, the National Sword and other campaigns were started. According to incomplete statistics, $85 \%$ of the Chinese waste plastics recycling market was under strict environmental protection controls by 2017 [24]. More than 5-6 million enterprises in 28 cities were sanctioned for violations in 2017. Sanctions included stopping production, criminal detention, and censure [24].

There have been some reports that about $5 \%$ of largescale recycling enterprises have started collecting domestic waste plastic, another 5\% have left China to set up factories in Southeast Asian or "waste origin" countries (i.e., Europe, the United States, and Japan), and the remaining 80-90\% have been forced to close [26]. However, it is difficult to determine whether companies have gone dormant or bankrupt, and there is little to no evidence that these ratios are correct.

Before 2017, China imported 6-7 million t of waste plastics, but this amount decreased drastically after the China Ban (Fig. 2). How did industries cover the existing demand for these millions of tons of waste plastics? There are generally three ways to supplement the shortage of these materials: (1) use virgin plastics, (2) import half-finished products (recycled plastic pellets), and (3) use domestic waste plastics. One Chinese waste plastic importer said he had never considered using domestic waste plastic because the collection cost is so high. In practice, many businesses have increased the use of virgin plastics or imported recycled pellets, depending on market prices.

As noted above, since it has become very difficult to import waste plastics to China, some Chinese recyclers relocated their factories outside of China, especially in Southeast Asian countries. Southeast Asia has several advantages as compared to other developed countries: (1) it is easier and faster to get a license for plastic recycling business in these countries, (2) there is a tariff exemption based on the ASEAN China Free Trade Agreement, and (3) shipping costs are reasonable.

In 2016, China Plastic Recycling Association called for participation from member companies to visit Southeast Asia (Malaysia, Vietnam, and Thailand), Japan, Korea, and Europe to expand their business abroad. The main purpose was to find good foreign suppliers of recycled pellets. These efforts were in line with China's "Go Global" (Zou Chu Qu) policy and "The Belt and Road Initiative" (Yi Dai Yi Lu).

As a result, a large volume of waste plastics began to be pelletized in ASEAN countries and exported to China. Since the HS code for recycled pellets is the same as for virgin plastics, the exact amount of imported recycled pellets cannot be determined from trade statistics. A Chinese waste plastic recycling industry report estimated that approximately 3 million t of recycled pellets were imported to China in 2018 [27]. It is also interesting to point out that the destination of waste plastics has moved from Malaysia and Thailand, known as highly regulated countries, to less regulated countries (such as Vietnam, Indonesia, etc.). 


\section{Domestic collection and recycling}

Can the amount of waste plastic generated in China meet the demand for plastic resources in China? Domestic collection and recycling amounts of waste plastics from 2011 to 2018 are shown in Fig. 3. Because of the Green Fence campaign, the environmental protection atmosphere in China was strong in 2013, and the motivation for domestic waste plastics collection was relatively weak. In 2014, China's environmental protection situation was slightly relaxed, and its recycling volume increased slightly. In 2015 , the recycling volume decreased again not only as a result of environmental protection and rectification factors, but also because many small and medium-sized enterprises had gone out of business. In 2018, the domestic waste plastic recycling volume was 18.3 million $\mathrm{t}$, an increase of 1.37 million t from 2017. As the volume of imported waste plastics dropped by $99 \%$, motivation for domestic recycling sharply increased and the recovery volume of some products with relatively complete recycling systems (e.g., waste PET) increased. In terms of prices, the sharp decline in imported waste plastics led to shortages in the domestic waste plastics market, and the average price of most waste plastics increased by $6-16 \%$ in 2018 as compared with 2017 [28]. In my interviews with Chinese plastic recyclers, they indicated that the consumption of virgin plastics is increasing because of the higher prices for recycled materials.

Domestic demand for recycled plastics

Domestic collection and recycling amount of waste plastics

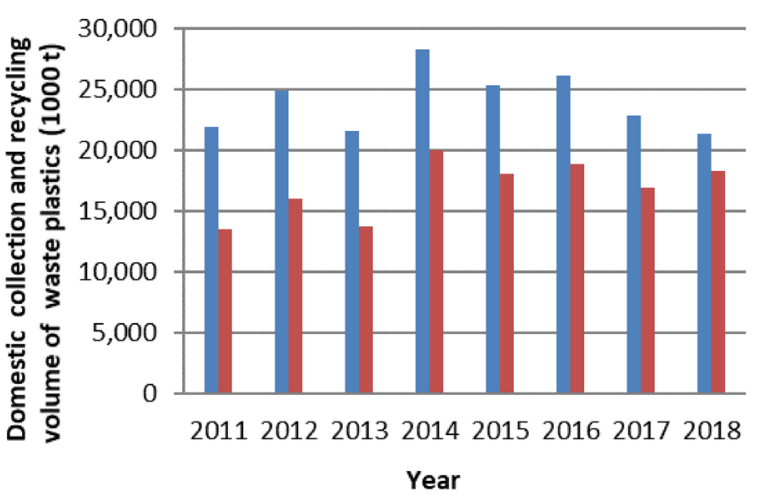

Fig. 3 Volume of domestic collection and recycling of waste plastics and demand for waste plastics. Note: Data for 2011-2017 are from the Chinese Plastic Recycling Association [24]; data for domestic collection amount in 2018 are from the Ministry of Commerce of the People's Republic of China [28]; data for domestic collection amount in 2018 are from the Ministry of Commerce of the People's Republic of China (2019); domestic demand in 2018 was estimated by the author (the total is based on the following assumptions: 52,000 t waste plastic imports and 3 million $t$ recycled pellets)
Impact on the Taiwanese plastic recycling industry

\section{History of waste management in Taiwan}

Taiwan once had the nickname "Garbage Island" because the island struggled to clean up the waste resulting from rising living standards and soaring consumption. As late as the mid-1990s, recycling in Taiwan was not regulated and waste problems were negatively impacting the environment and human health. In 1998, the Waste Disposal Act was amended to promote and formalize recycling activities and waste reduction. It also introduced an extended producer responsibility scheme. In response to this requirement, Taiwan's Environmental Protection Administration (EPA) introduced the "4-in-1 Recycling Program," which includes local residents, recyclers, local government, and a newly established recycling fund into one complete system [30]. A government fund was established to encourage recycling. Under the system, manufacturers and importers pay a fee based on the estimated cost of collection and recycling. The EPA then distributes those fees to recycling companies.

This system has provided appropriate economic incentives for the recycling industry to develop, it also created value-added and employment opportunities. Taiwan's recycling rate has been increasing every year since the system was put in place, and in 2018, it exceeded $60 \%$. It has achieved the world's second highest recycling rate, following Germany [31]. The 4-in-1 Recycling Program has been very successful and has been well received by governments in other countries.

\section{History of recycling industries in Taiwan}

Taiwan was a global center for shipbreaking after the end of World War II through the 1980s. Taiwan's waste metal and electrical appliance scrap recycling industry was also developed during this period [32]. Later, Taiwan also began to import scrap household appliances and electrical wires from the United States, Europe, Japan, and other countries. However, because of the environmental pollution associated with the open burning of cables and wires, the import of waste metals has been regulated since 1983, and it was almost completely banned in 1992. The world's ship dismantling industry has shifted from Taiwan to other South Asian countries, and the recycling of waste metal scrap has also shifted from Taiwan to mainland China and other countries in Southeast Asia.

In 1998, a serious incident was uncovered in which waste containing mercury was exported from Taiwan to 
Cambodia [33]. The exported waste, believed to be compressed waste cement, was dumped a few miles outside Sihanoukville, and the Taiwanese government was criticized by the Cambodian government in the international media. This incident led to the revision of the Waste Management Act in 2001, which controls both the import and export of all wastes (both general waste and industrial waste). In an interview, a representative of the Formosa Association of Resource Recycling said that, "not even a single wire is allowed to be imported in a waste paper container."

\section{Import statistics}

According to import statistics, the average monthly volume of waste plastics imported before the China Ban was about $15,000 \mathrm{t}$ in 2016 (Fig. 4). The import volume suddenly increased after September 2017, reaching a peak of 53,000 $\mathrm{t}$ in September 2018. Similarly, the import volume of waste paper started to increase in the second half of 2017, peaking at 150,000 t, 2.6 times the monthly average from the previous year (Fig. 5).

Although the trade statistics show that imports doubled or tripled after the Ban, some news media have reported much greater increases, for example, "The export from the United Kingdom to Taiwan has increased 10 times" [34] and "Taiwan is the world's garbage dumping ground" [35]. It was also reported that the importation of poor-quality waste paper and waste plastic from abroad had increased [35]. Based on my interviews with officials of the Taiwan Plastics Industry Association in February 2019, Taiwanese waste plastic recyclers were pleased with the China Ban, which allowed Taiwanese recyclers to import high-quality materials more easily. A comment expressing a typical statement
Fig. 4 Volume of imported waste plastics in Taiwan. Source: The Bureau of Foreign Trade, Ministry of Economic Affairs, Taiwan [29]
Fig. 5 Volume of imported waste paper in Taiwan. Source: The Bureau of Foreign Trade, Ministry of Economic Affairs, Taiwan [29]
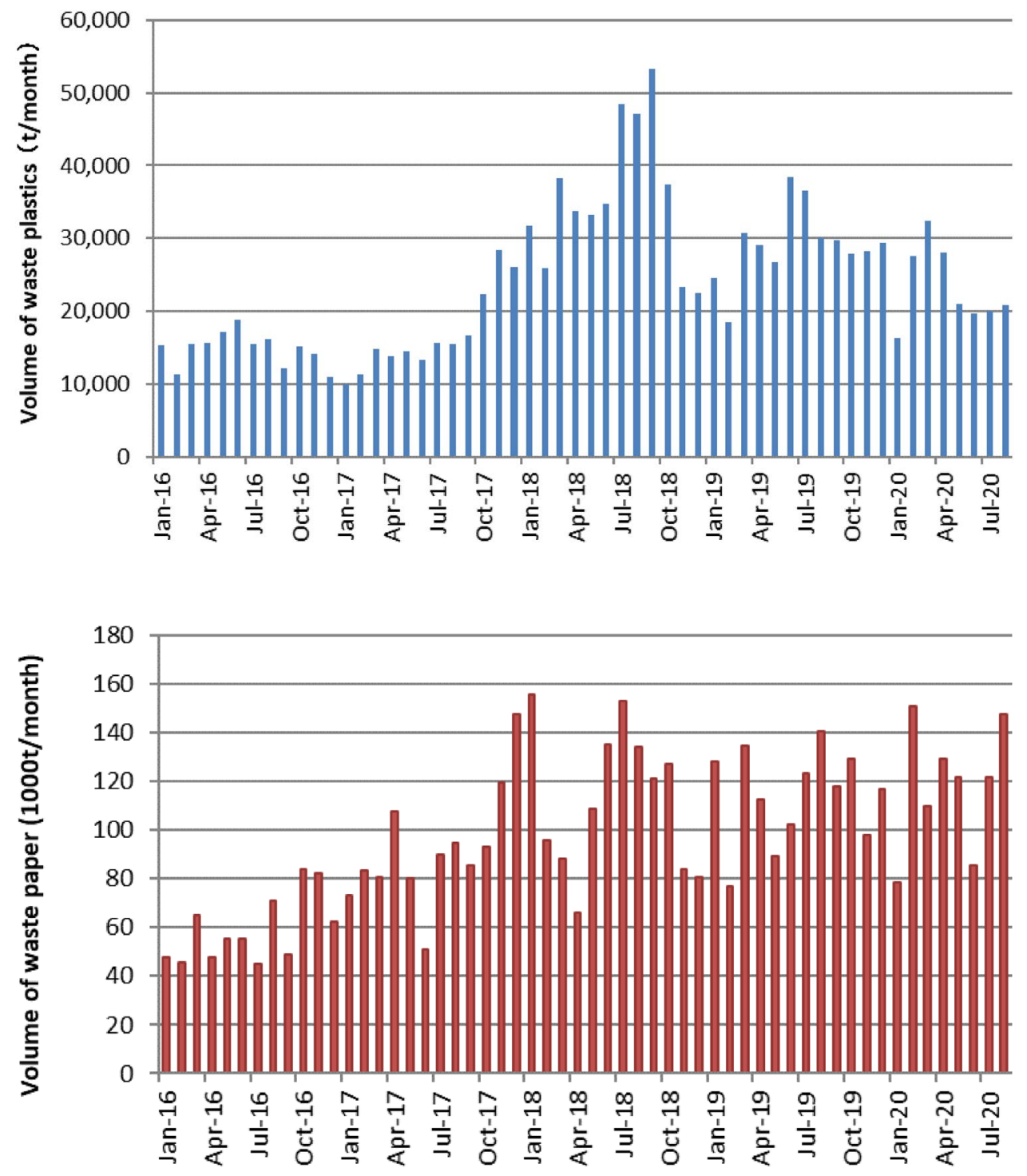
was, "In the past, because China always offered high prices, Taiwanese companies were not able to buy materials that they wanted at suitable prices." Taiwan has frequent customs inspections of imported materials, and Taiwan's EPA has an Environmental Inspection Team that supports the execution of environmental protection services by local governments. Their job is to conduct supervision and control of waste disposal matters and do follow-up surveys of illegal dumping. Because of these robust inspection systems, no illegal incidents have been reported, even after China's import ban.

\section{New regulations}

Although there appears to be a gap between media reports and trade statistics and reports from people working in the industry, environmental protection groups advocated that Taiwan should control the importation of waste paper and waste plastics in a similar manner as Southeast Asian countries [36]. In response to a request from environmental protection groups and the Legislative Yuan, the EPA announced that regulations would be strengthened in August 2018.

On 1 October 2018, Taiwan's EPA issued an amendment of Bulletin 1 of its "Industrial Waste Required as Materials for Industrial Use" [37]. Only legal (i.e., authorized and regulated) enterprises would be allowed to import waste plastics and waste paper. The standard for waste plastics was limited to a single material and a single type, and only kraft, corrugated, or deinked paper could be recycled. This amendment was intended to control the quality of source material and regulate the use of recycled materials on the back-end. The EPA also announced that it and the local Environmental Protection Bureaus were going to require these legal factories to disclose their operating records and achieve effective management of back-end users in the future. In addition, the EPA said it would continue to strengthen border inspections in coordination with the Department of Finance's Customs and Excise Department to control the quality of source materials.

In my interviews, officials in Taiwan's plastic industry said that they had no particular problem with the new regulation. Many companies had already started importing a single type of plastic material because importing mixed plastics to Taiwan is not feasible because the labor cost associated with the sorting process is too high. However, some recyclers noted that some mixed plastics could previously be imported together if they were "good looking," but now they were restricted to importing only one type of plastic. In general, they thought the law may be too strict and that the new regulations may be too strict to promote recycling.

After the new regulations went into force in October 2018, the volume of imported waste plastics decreased, whereas the volume of imported waste paper remained stable or increased (Figs. 6 and 7). These differences may stem from differences in industrial structure in these sectors.

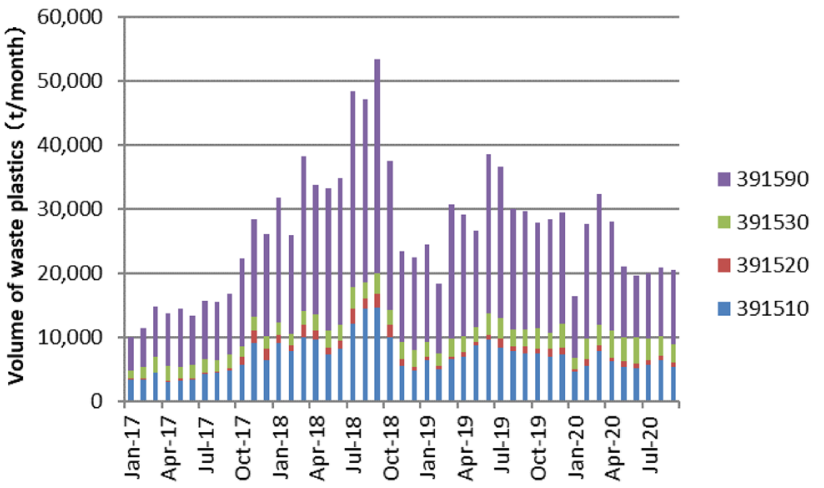

Fig. 6 Amount of imported waste plastics in Taiwan by type. Note: 391510: Ethylene polymers; 391520: Styrene polymers; 391530: Vinyl chloride polymers; 391590: Other plastics. Source: The Bureau of Foreign Trade, Ministry of Economic Affairs, Taiwan [29]

The waste paper industry consists of medium to large paper manufacturers, and the industry is oligopolistic. On the other hand, the waste plastic industry consists of many small to medium companies and is highly competitive. Another difference is that because of a shortage of high-quality domestically collected waste paper, Taiwanese paper manufacturers have had to import foreign waste paper, which generally have longer fibers, to improve the quality of domestically recovered waste paper [38].

\section{Discussion and conclusion}

The purpose of this study was to examine the background of the China Ban and its impacts on waste plastics industries and trade in China and Taiwan.

The major reason for the adoption of the Ban in 2017 was China's desire for greater environmental protection, and it appears highly unlikely the Ban will be relaxed. To fill the raw material shortage caused by the Ban, the Chinese government introduced regulations on waste separation to increase the volume of recycled domestic waste plastics, but it will not be easy to build a comprehensive collection system in a short period. In the meantime, China has increased the use of virgin materials and imported recycled pellets. Some Chinese waste plastic recycling companies have transferred their factories to Southeast Asia, Japan, and Taiwan and started to export recycled pellets to China.

After the China Ban, imports of waste plastic and waste paper increased by a factor of two to three as compared with the previous year's amounts in Taiwan. Although no illegal waste recycling incidents have been reported in Taiwan, Taiwan enacted new regulations on the importation of recyclable waste on 1 October 2018 because of pressure from environmental protection groups. However, the situation in Taiwan is fundamentally different compared to that 
Fig. 7 Amount of imported waste paper in Taiwan by type. Note: 470710: unbleached kraft paper or paperboard or of corrugated paper or paperboard; 470720: waste and scrap, paper or paperboard made mainly of bleached chemical pulp, not colored in the mass; 470730: waste and scrap, paper or paperboard made mainly of mechanical pulp; 470790: unsorted waste and scrap of paper or paperboard. Source: The Bureau of Foreign Trade, Ministry of Economic Affairs, Taiwan [29]

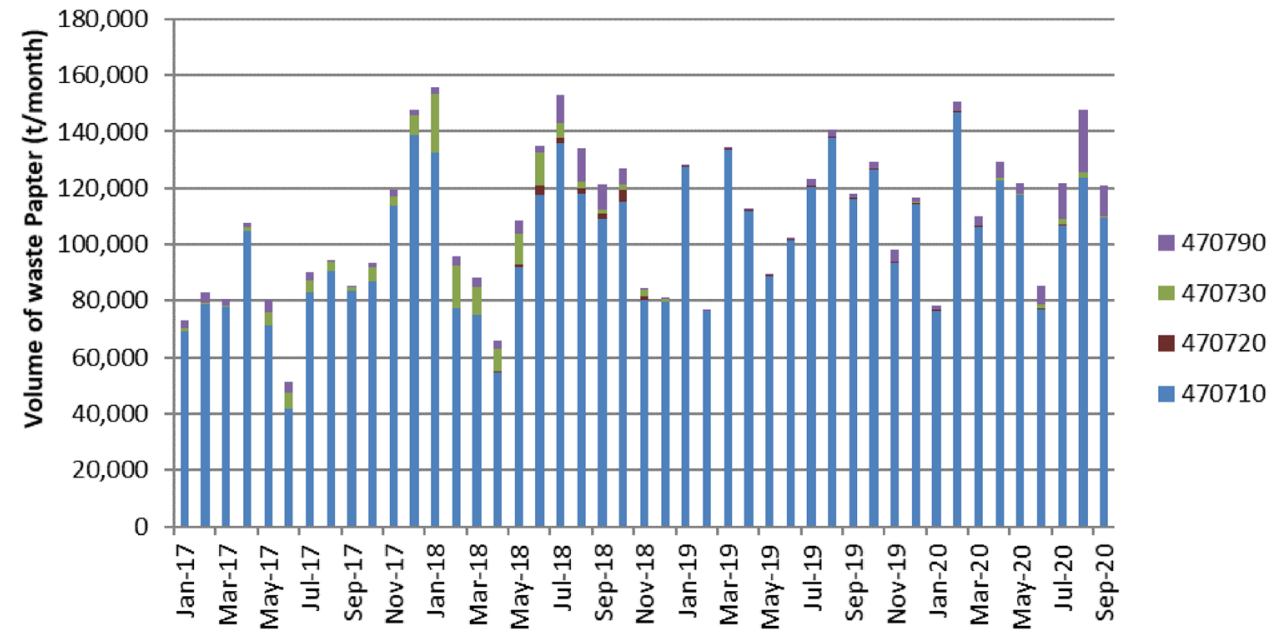

in Southeast Asian countries. Taiwan has a long history of strict border inspections on both the import and export of waste materials, whereas the Southeast Asian countries suffer from problems associated with improperly classified waste because of their relatively loose import controls. Another reason is that Taiwan's recycling industry is well developed, and Taiwan has not relied too heavily on exports as a solution to the disposal of domestically collected waste. Many Taiwanese recycling companies have also been interlinked with the Chinese recycling industry because they relocated their factories to China at an early stage.

The China Ban has entirely changed international trade in waste plastics. The recycled pellet trade can be evaluated as a better solution than the waste plastic trade because it prevents environmental pollution in the importing countries, but the processing of waste plastics into pellets in third countries might lead to a transfer of environmental pollution from China to the pellet-producing countries. In addition, the use of virgin plastics has increased in China. Therefore, we should be careful when evaluating whether or not the global environmental burden has been reduced as a result of the China Ban.

To this point, our understanding of the effects of the China Ban is mostly based on limited qualitative information. A very recent life-cycle analysis on waste PET recycling indicated that the China ban may increase environmental impacts both in China and globally if China meets its PET fiber shortage by increasing domestic virgin fiber production [39]. The case of Taiwan indicates that import control plays an important role in sustaining the benefits of the global circular economy by replacing virgin natural resources with recycled resources and thereby reducing the environmental burden.

Acknowledgements This work was supported by the research study, "Impact of Non-Tariff Measures on Recyclable Waste," of the Economic Research Institute for ASEAN and East Asia, and he
Grant-in-Aid of the Japan Society for the Promotion of Science (Grant number 18KT0001).

Open Access This article is licensed under a Creative Commons Attribution 4.0 International License, which permits use, sharing, adaptation, distribution and reproduction in any medium or format, as long as you give appropriate credit to the original author(s) and the source, provide a link to the Creative Commons licence, and indicate if changes were made. The images or other third party material in this article are included in the article's Creative Commons licence, unless indicated otherwise in a credit line to the material. If material is not included in the article's Creative Commons licence and your intended use is not permitted by statutory regulation or exceeds the permitted use, you will need to obtain permission directly from the copyright holder. To view a copy of this licence, visit http://creativecommons.org/licenses/by/4.0/.

\section{References}

1. Yoshida A (2005) China: the world's largest recyclable waste importer. In: Kojima M (ed) International trade of recyclable resources in Asia. Institute of Developing Economies, pp 33-52.

2. Zhou HC Editor-in-Chief (2008) Turning waste into treasure: research on China's resource recycling industry and policy. Science Press (in Chinese)

3. Li HY, Feng DF (2007) Study on recycle and environmental management policy of imported waste in China. Recycl Resour Circ Econ 3:5-9 (in Chinese)

4. Li S, Lan X, Ju H, Liu G (2016) Cliff-type ban on waste plastic imports is not advisable. Environmental Economy, 23:42-46 (in Chinese)

5. Qiu Q, Zheng Y, Han F, Liu G, Li SY, Hu HL (2011) Co-benefit analysis on environmental management of imported waste recycling in China. Environ Sustain Dev 36(06):26-29 (in Chinese)

6. Pang K, Liu MC, Zhao ZC, Li YM, Hou BC (2010) Discussion on imported solid wastes as raw material. Recycl Resour Circ Econ 3(10):29-31 (in Chinese)

7. Yoshida A (2013) Recyclable waste trade of Mainland China. In: Kojima M, Michida E (eds) International trade in recyclable and hazardous waste in Asia. Edward Elgar, Cheltenham, pp 33-50

8. Zhang C (2017) What signals released from the entry ban of foreign garbage? China Environment News. April 28, 2017 (in Chinese) 
9. The General Office of the State Council (2017) Implementation plan for the reform of the import management system of solid wastes for the prohibition of foreign waste imports (in Chinese). http://www.gov.cn/zhengce/content/2017-07/27/content_5213738. htm. Accessed 11 Nov 2020

10. Brooks AL, Wang S, Jambeck JR (2018) The Chinese import ban and its impact on global plastic waste trade. Sci Adv. https://doi. org/10.1126/sciadv.aat0131

11. Yang S (2020) Trade for the environment: transboundary hazardous waste movements after the Basel convention. Rev Policy Res. https://doi.org/10.2139/ssrn.3386820

12. Wang W, Themelis NJ, Sun K, Bourtsalas AC, Huang Q, Zhang Y, Wu Z (2019) Current influence of China's ban on plastic waste imports. Waste Disposal Sustain Energy 1:67-78. https://doi.org/ 10.1007/s42768-019-00005-Z

13. Qu S, Guo Y, Ma Z, Chen WQ, Liu J, Liu G, Wang Y, Xu M (2019) Implications of China's foreign waste ban on the global circular economy. Resour Conserv Recycl 144:252-255. https:// doi.org/10.1016/j.resconrec.2019.01.004

14. Freytas-Tamura KD (2018) Plastics pile up as china refuses to take the west's recycling. The New York Times. https://www.nytimes. com/2018/01/11/world/china-recyclables-ban.html. Accessed 11 Nov 2020

15. Profita C, Burns J (2017) Recycling Chaos in U.S. As China Bans 'Foreign Waste', National Public Radio. https://www.npr. org/2017/12/09/568797388/recycling-chaos-in-u-s-as-china-bansforeign-waste. Accessed 11 Nov 2020

16. Finn C (2018) China took 95\% of Ireland's plastic waste - but now it's changed its mind and we're in trouble, the journal.ie. https://www.thejournal.ie/ireland-plastic-waste-3786393-Jan20 18/. Accessed 11 Nov 2020

17. Hanawa K, Abe D, Fukui K (2019) Plastic waste searches for a new home as Asia shuts its gates, Nikkei Asia. https://asia.nikkei.com/Spotlight/Environment/Plastic-waste-searches-for-a-newhome-as-Asia-shuts-its-gates. Accessed 11 Nov 2020

18. Yoshida A (2019) China's waste plastic import restrictions and its impact on domestic recycling. Environ Econ Policy Stud 12(2):50-53 (in Japanese)

19. CBS News (2019) Malaysia vows to send tons of non-recyclable garbage back to U.S., other developed nations. https://www.cbsne ws.com/news/malaysia-plastic-waste-back-to-us-other-developednations-trash-crisis-china-recycling/. Accessed 11 Nov 2020

20. Sasaki S (2019) Current situation and issues of plastic problems in Thailand. Environ Econ Policy Res 12(2):46-50 (in Japanese)

21. Li S, Yang Z, Hao Y, Ju H, Zhou B, Yu H (2011) The development strategies of classification management list of imported wastes in China, Environ Sustain Dev 36(2): 45-49 (in Chinese)

22. Ministry of Environmental Protection (MEP) of China (2008) Import waste management in China, seminar on import/export management of export waste to china (May 8, 2008 in Tokyo). https://www.env.go.jp/recycle/yugai/seminar/seminar080508/3_ MEP_EN.pdf. Accessed 11 Nov 2020

23. Zheng Y, Qiu Q, Li S, Ju H, Zhang Z, Hu H (2011) Research on environmental management of imported recyclable waste and protection measures of environmental risks. Environ Sustain Dev 36(6):46-50 (in Chinese)

24. China Plastic Recycling Association (2017) Development Report of China Plastic Recycling Industry 2017-2018 (in Chinese)

25. UN Comtrade Database. https://comtrade.un.org/. Accessed 11 Nov 2020
26. China Plastic and Rubber Journal (2017) Because of sharp decrease of waste plastics import, the waste plastic industry was bifurcated (in Chinese). https://www.adsalecprj.com/Publicity/ MarketNews/lang-simp/lang-simp/article-67028294/article-67028 294/NewsArticle.aspx. Accessed 11 Nov 2020

27. Yamashita $T$ (2018) Shift from international recycling of waste plastic to domestic recycling (in Japanese). https://www.pwmi.or. jp/public/new/201902/index.html. Accessed 11 Nov 2020

28. Ministry of Commerce of the People's Republic of China (2019) China Renewable Resources Industry Development Report 2019 (in Chinese). http://ttfzs.mofcom.gov.cn/article/ztzzn/an/201910/ 20191002906058.shtml. Accessed 11 Nov 2020

29. The Bureau of Foreign Trade, Ministry of Economic Affairs, Taiwan. https://portal.sw.nat.gov.tw/APGA/GA30E. Accessed 11 Nov 2020

30. Bor YJ, Chien YL, Hsu E (2004) The market-incentive recycling system for waste packaging containers in Taiwan. Environ Sci Policy 7(6):509-523

31. Eunomia (2018) Recycling-who really leads the world? European Environmental Bureau. https://eeb.org/library/recycling-whoreally-leads-the-world/. Accessed 13 July 2021

32. Terao $\mathrm{T}$ (2008) Shipbreaking and metal recycling industries in Taiwan. In: Kojima M (ed) The promoting 3Rs in developing countries: lessons from Japanese experience. Institute of Developing Economies-JETRO, Chiba, pp 59-79

33. New York Times (1998) Tests show high mercury at Cambodia dump site. https://www.nytimes.com/1998/12/26/world/testsshow-high-mercury-at-cambodia-dump-site.html. Accessed 13 July 2021

34. Financial Times: British plastic waste exports to Taiwan increased by more than 10 times (in Chinese). https://technews.tw/2018/06/ 20/plastic-waste-export-tide-turns-to-south-east-asia-after-chinaban/. Accessed 11 Nov 2020

35. Apple Daily's special issue on foreign waste (in Chinese). https:// tw.inv.appledaily.com/waronwaste/. Accessed 11 Nov 2020

36. EX Corporation (2019) Report on investigation and review of import regulations on plastic scraps, etc. in FY2018 (in Japanese). https://www.env.go.jp/recycle/yugai/pdf/houkoku_h30. pdf. Accessed 11 Nov 2020

37. Taiwan Environmental Protection Administration (EPA) (2018) Strict import qualifications and standardizing waste plastic and waste paper quality (in Chinese). https://enews.epa.gov.tw/enews/ fact_Newsdetail.asp?InputTime $=1071001135117$. Accessed 11 Nov 2020

38. Taiwan EPA (2019) Taiwan EPA circulated on the recent news on imported waste paper and waste plastic on the Internet once again (in Chinese). https://enews.epa.gov.tw/Page/3B3C62C788 49F32F/bb6fc827-e1f8-496e-8cf7-ca24cba02f56. Accessed 11 Nov 2020

39. Ren Y, Shi L, Bardow A, Geyer R, Suh S (2020) Life-cycle environmental implications of China's ban on post-consumer plastics import. Resour Conserv Recycl. https://doi.org/10.1016/j.resco nrec.2020.104699

Publisher's Note Springer Nature remains neutral with regard to jurisdictional claims in published maps and institutional affiliations. 